\title{
The Inclusive Education in Europe
}

\author{
Beatriz Manzano-García ${ }^{1}$, María Tomé Fernández ${ }^{2, *}$ \\ ${ }^{1}$ Faculty of Education, Granada University, Spain \\ ${ }^{2}$ Faculty of Social Sciences and Humanities of Teruel, Zaragoza University, Spain
}

Copyright $(\mathcal{C} 2016$ by authors, all rights reserved. Authors agree that this article remains permanently open access under the terms of the Creative Commons Attribution License 4.0 International License

\begin{abstract}
One of the phenomena that is of most concern to educational policy in Europe is immigration due to the fact that this is the source of new educational needs. This research looks at how European educational legislation deals with this topic. For this intercultural values that make inclusive education will be evaluated, we will analyze intercultural values in 32 laws. The qualitative analysis will be through the Atlas software IT using a system of categories previously validated. Among the most important conclusions drawn we can point out that all countries transmit intercultural values in their educational laws. Moreover, the most transmitted values are the primary intercultural values, (social, moral and transcendental ones).
\end{abstract}

Keywords Human Rights, Values, Europe, Inclusive Education

\section{Introduction}

In the last decades, the migratory movement between continents has caused the massive growth of the population in some countries. At the same time, this fact has been increasing new educational needs in students from those countries. This phenomenon has caused the emergence of educational challenges related to multiculturalism, immigration, attention to diversity and compensatory education [20]. Inclusive education emerged to respond to these new educational challenges in the Jomtien World Conference (1990) [24]. From this moment, educational legislation began to include the concept of inclusive education.

What really happens in European countries? Are such values reflected in their basic laws? Or otherwise, do the educational laws not reflect this paradigm? This research tries to respond to these questions. To achieve this goal, we will analyze the educational laws of 32 European countries in order to know firstly, if the concept of inclusive education is included in the basic educational laws. Secondly, how intercultural values are transmitted in European laws.

\subsection{The Intercultural Inclusive Education}

This paradigm emerged to prevent segregated educational practices for special students [4, 5, 12, 21, 41]. In Europe the concept of inclusive education develops according to the international education laws. That concept focuses its efforts on the educational non-exclusion of people who are disadvantaged both culturally and economically. Therefore, this concept includes the pupil with special educational needs [8].

As the matter of fact, this is obviously an education that attends and responds to the educational needs of each and every one of the students. [7]. in this paper, we refer to the inclusion of students from different cultures.

However, the current reality of many schools reflects some problems of coexistence due to the incorporation of students from different backgrounds in the education system.

The implication of $[4,2,37]$ inclusive education is the best way to solve these problems. Inclusive education is based on values that guarantee among students a fair, ethical, democratic, egalitarian and social education [33]. Values have emerged from the Universal Declaration of the Human Rights (1948) [34]. Moreover we can highlight those of equity, respect for diversity, compassion, self-realization, tolerance and participation [37].

According to Rios [27] schools value each student's characteristics, promoting the development of individual skills and self-improvement. Also, we propose to facilitate equal opportunities in access to a curriculum of high value culturally and free from discriminatory aspects. To achieve this purpose, the starting point will be to consider that all students will be able to receive an education in values. It will be necessary to work in an adequate environment. So, all members of schools should promote the quality of educational and personal development. Then we will consider diversity as a necessary positive aspect for the social union and new opportunities of learning. [1, 4, 27].

\subsection{The Importance of Education in Intercultural Values for Inclusive Education}

The current schools reflect the cross-cultural 
characteristics of societies to which they belong. In these schools, there are problems of coexistence that arise as a result of cultural diversity and lack of knowledge towards the characteristics and peculiarities of students from diverse backgrounds [38].

It is necessary to respond to these new educational problems to educate at the students in values [40]. This type of education promotes different cultural experiences. At the same time it improves communication in schools $[9,29,30]$. Therefore, a kind of intercultural education creates democratic and competent citizens for the peaceful coexistence in schools [36].

In this paper we analyze European transmission in educational laws of intercultural values. Previous studies [10, $17,18,26]$ have shown this type of values education. According to those authors, it would be quite important to educate citizens in values for living in a democratic environment. This kind of education in values will create many cultural experiences between members of schools. So, students will enrich their learning, acquiring beneficial habits and behavior at the same time.

\subsection{Intercultural Values and Human Right}

The intercultural coexistence should be perceived as an enriched and social fact. It will encourage learning about others and respecting them. The United Nations (2002) explains that human rights are specific to human beings and without them we cannot live with quality. These rights are composed of different values that form a code of conduct applicable to all persons irrespective of their religion, cultural level, political belief or social status. The classification most famous is Human Rights that distinguishes three generations [13]. In these generations, dignity is the common value that emerges from different human rights.

The Universal Declaration of Human Rights [11] recognizes dignity as a value formed by the right to life and to security and that underlies in addition to other values like that of liberty, equality, difference staff???, autonomy and personal responsibility.

First generation Human Rights are those related to civil and political rights. These rights include rights related to the exercise of freedoms, the right to life, the right to think and express them freely, the right to personal difference, the right to equality, the right to security, the right to family privacy, the right to religious freedom, the right to property. [13]

Freedom is the one value that supports the human rights of the first generation. This value is defined as the capacity that human beings perform any act or decision, without any imposition or coercion of another person [25].

The second-generation human rights are concerned with economic, social and cultural rights, i.e., the right to receive a living wage, the right to the human realization in work, the right to work, the right to social security, the right to education, the right to education, the right to holidays, the right to leisure and the environment [13]. These rights will provide economic and social conditions. They are based in the first generation rights.

Second generation rights emerge from the values of equality and participation. According to Pérez [25] equality is defined as the value that enables the human being or organism to treat the rest of humanity without discrimination regardless of sex, race, social class or other circumstance which makes it different from the rest. And participation as the value that enables the individual to work together with other subjects creating ties of cohabitation in a common project.

Finally, third generation Human Rights include the right to peace, to computer new freedoms, and to the rights related to the quality of life, including in the latter the right to the environment [13]. Solidarity is the main value of this generation. [22] This value was created to support other values as detachment, generosity, spirit of cooperation and participation.

In this research we analyze a category system of values that is called intercultural values. The system of categories reflects (view Appendix) the values that support human rights. For this study, intercultural values are classified according to [35]:

\section{Primary intercultural values}

- Moral and ethical values: Attitudes and actions (right and duty).

- Social values: Behavior in social groups.

- Transcendental values: Attitudes and actions about religion and the Divinity.

\section{Secondary intercultural values}

- Intercultural values (intellectual/ non ethical): Cultural knowledge, instructional interest and cultural environments.

- Productive values: Social and material goods.

- Change values: Attitudes and actions about adaptation, improvement and innovation.

3. Tertiary intercultural values: They facilitate the acquisition of primary and secondary values:

- Vital values: Attitudes and actions about basic needs, leisure, human health and hygiene.

- Aesthetic values: Beauty and artistic activities.

- Personal development values: Self-realization, self-assertion and the development of personal qualities.

- Ecological values: Attitudes and actions about the safety of Nature.

\section{Materials and Methods}

\subsection{Method}

\subsubsection{Sample}

The sample is comprised of the laws of Basic Education for 32 countries of the European continent $(\mathrm{N}=32)$. This is a 
non-probabilistic sampling, in which intentionally selected the educational legislation that by language and ease allowed its analysis. It has analyzed the legislation of Albania, Armenia, Germany, Azerbaijan, Belarus, Belgium, Bosnia \& Herzegovina, Cyprus, Croatia, Denmark, Spain, Slovakia, Estonia, Finland, France, Greece, Hungary, Iceland, Ireland, Italy, Lithuania, Luxembourg, Malta, Netherlands, Norway, Poland, Portugal, Prague, Russia, Sweden, Turkey and United Kingdom.

Table 1. Legislation analyzed and the corresponding European country.

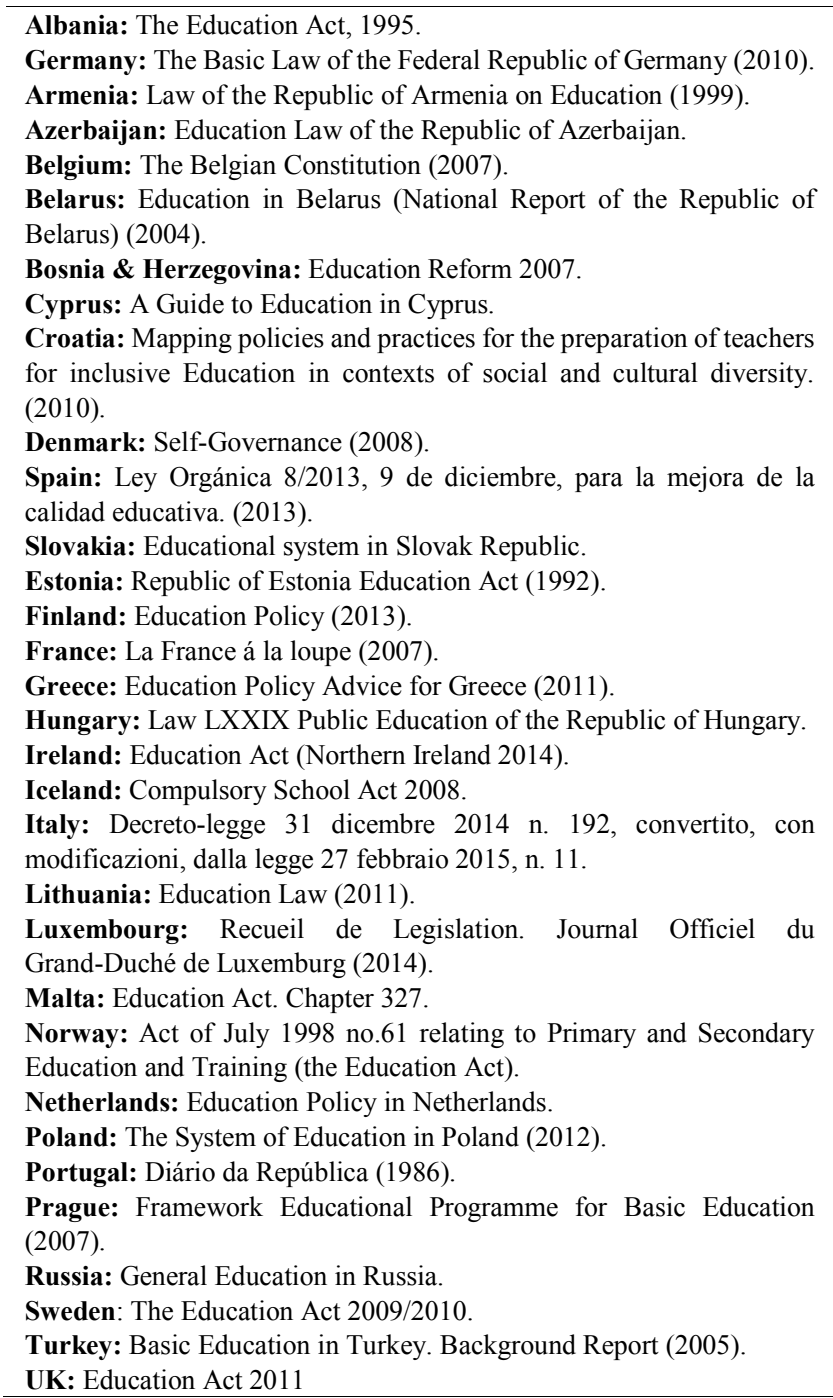

\subsubsection{Assessment Tools}

In this study we used a system of categories of values previously validated in others international studies $[35,36]$. The system of category is composed of 3-dimensions (primary, secondary and tertiary), 11 categories (moral and ethical, social, transcendental, intellectual/non-ethical, production, change, vital, affective, aesthetic, personal development and ecological), 23 subcategories as (good option, option by duty, social group and social position, social improvement, religious, Divinity, cultural knowledge, instructional interest, cultural environment, property, social property, needs of fun, human health and hygiene, basic needs, family relationships, friendships, relationships of couple, beauty, artistic activity, self-fulfillment, self-affirmation and personal qualities) and finally 78 values. (View appendix A).

\subsubsection{Procedure}

In this paper the laws of basic education have been analyzed from 32 European countries. The laws were analyzed applying the system of categories.

\subsubsection{Data Analysis}

The data analysis has been performed by the software named ATLAS. Ti. So, in this paper we used a qualitative methodology. The values in each law will be counted. Also, the percentages have been normalized using the following formula:

$$
\% \text { subcategorie }=\frac{\text { Subcategorie value } x 100}{\text { Total values }}
$$

\subsubsection{Results}

The following tables show (see Appendix B) an evaluation of the frequencies of intercultural values obtained in each of the laws of basic education.

It is shown in Table 2 that Albania (96.02\%), Germany $(100 \%)$, Armenia $(66.02 \%)$, Belgium (100\%), Belarus (73.98\%), Bosnia \& Herzegovina (85\%), Cyprus (40.41\%), Croatia $(96.3 \%)$ and Denmark $(76.47 \%)$ transmit high percentages in these dimensions: primary values (ethical and moral, social and transcendental values). In these countries the transmission of ethical and moral values are higher than other values (Albania $65.89 \%$, Armenia $44.23 \%$, Belarus $50.69 \%$, and Denmark 58.83\%). Also, the transmission of social values is higher in these countries (Germany $80 \%$, Belgium 50\%, Bosnia \& Herzegovina $65 \%$ and Croatia $59.26 \%$ ).

On the other hand, secondary values (intellectual/non ethic, productive and change values) are lower in the educational laws of Albania (0.64\%), Germany $(0 \%)$, Belgium (0\%), Belarus (10.96\%) and Cyprus (25.53\%). However Azerbaijan transmits $40.92 \%$ of intellectual/non ethic values and $1.30 \%$ of productive values in its law.

In countries such as Armenia (18.56\%), Bosnia \& Herzegovina $(0 \%)$, Croatia $(0 \%)$ and Denmark $(5.88 \%)$ the tertiary values (vital, affective, aesthetic, personal development and ecologic) are the least transmitted in their educational laws.

Therefore, as is shown in the Table 3 primary values are higher in the European legislation than in Spain (81.12\%), Estonia (79.56\%), Finland $(100 \%)$, Greece $(86.38 \%)$, Hungary (100\%), Ireland (100\%), Island (80.36\%) and Italy $(82.15 \%)$. Also, moral and ethical values are the most transmitted in some countries such as Spain $(58.49 \%)$, Estonia (63.65\%), Greece (59.13\%), Ireland (80\%), Island $(71.43 \%)$ and Italy $(62.45 \%)$. However, social values are the most transmitted in Finland (57.15\%). 
On the other hand, secondary values are least transmitted in Spain $(7.54 \%)$, Slovakia (0\%), Estonia $(9.10 \%)$, Greece (4.54\%), Island (6.25\%) and Italy (6.69\%). However France transmits $75 \%$ of intellectual/non ethic values.

Finally as is shown in Table 3 tertiary values are higher in these countries Slovakia ( $40 \%$ of vital values and $20 \%$ of personal development values). In the educational laws of countries such as Finland, France, Hungary and Ireland the secondary and tertiary values do not appear

Table 4 shows the percentages of the primary values in countries like Lithuania (66.74\%), Luxemburg (46.43\%), Malta $(97.10 \%)$, Norway $(91.66 \%)$, Holland $(56.66 \%)$, Portugal $(47.60 \%)$, Sweden $(100 \%)$, Turkey $(57.14 \%)$ and UK (100\%). Moral and ethical values are most transmitted in Lithuania (64.44\%), Malta (95.65\%) and Holland (50\%). Social values are most transmitted in Luxemburg $(21.43 \%)$, Portugal $(35.70 \%)$, Sweden $(80 \%)$, Turkey $(33.33 \%)$ and UK (45\%). Finally, transcendental values are most transmitted in Norway (50\%).

Secondary values are less transmitted in Lithuania (4.44\%), Luxemburg (25\%), Malta (0\%) and UK (0\%). However, Poland transmits 50\% and Russia (100\%) of intellectual/non ethic values.

Finally, in the educational law of Prague appears $(24.56 \%$ of vital values, $4.38 \%$ of affective values, $15.79 \%$ of aesthetic values and $10.23 \%$ of personal development values). However in some countries these values are poorly transmitted like in Norway $(0 \%)$, Holland $(0 \%)$, Poland (16.66\%), Portugal (16.66\%) and Turkey (19.04\%).

In the educational law of Russia primary and tertiary values don't exist. Likewise secondary and tertiary values don't exist in Sweden and UK.

\subsubsection{Discussion}

This research rejected the initial hypothesis (all of the European educational laws transmit values. So, they don't promote the inclusive Education). According to the results, all European countries transmit values in their basic legislation. Therefore, primary values appear highly in the most of the laws analyzed.

On the other hand, Europe needs a new framework of values due to the current social changes. So, we need to guarantee in schools the teaching of values like democracy, tolerance and solidarity. [9]. According to another research $[35,39,15]$ we propose a need to educate in these values. These values emerged alongside Human Rights and it created inclusive education. An Inclusive Education is a type of Education whose main goal is educating all children in a classroom (also immigrants or students from different cultures or religions).

According to the results European laws transmit values. However, would this reason be enough to implement the inclusive Education in a country?

Some European countries like United Kingdom or Finland have a high quality educational system [34]. However, they only transmit primary values in their basic laws. According to this paper, these values are the most important elements in intercultural education [38]. So, we propose two arguments for futures studies.

Firstly, the countries that transmit only primary values in their educational laws, could implement more effectively inclusive education.

Secondly, we will propose to study other variables for futures research about countries whose basic laws transmit more primary values than others values like (Germany, Belgium, Finland, Hungary, Ireland, Sweden and UK). We couldn't analyze other variables that didn't appear in legislation.

On the other hand, we observed that the current economic development and inclusive Education are common thoughts in today's European society. Also, the main protagonists of this important phenomenon are educational systems, families and citizens. [34]. According to the results, the countries that transmit secondary or even tertiary values in their educational laws are Poland, Russia, Azerbaijan, France, Prague and Slovakia.

Finally, due to the diversity of educational characteristics of European countries, it would be necessary to prepare future research about why primary values are not transmitted.

\section{Conclusions}

The main findings obtained in this research were:

- All the European countries promote inclusive education in their legislation.

- Azerbaijan is the European country that more intercultural values transmit in its educational law.

- Germany, France, Hungary, Ireland and Sweden are the European countries whose laws less values transmitted. Therefore, in the basic laws of these countries don't appear the ecological value (tertiary dimension in the system of categories).

- The primary intercultural values like (moral, social and transcendental values) are the most transmitted by most countries. 


\section{Appendix}

Appendix A. Category system intercultural values (Tomé, 2012; Tomé \& Berrocal, 2013).

\begin{tabular}{|c|c|c|c|}
\hline Dimension & Category & Subcategory & value \\
\hline \multirow{7}{*}{ Primary intercultural values } & \multirow{2}{*}{ Moral and ethical values } & The option for the common good & Charity, goodness, generosity, help \\
\hline & & The option for the duties & $\begin{array}{l}\text { Commitment, honesty, obedience, } \\
\text { exemplify }\end{array}$ \\
\hline & \multirow{3}{*}{ Social values } & Social group & Equality, identity, community \\
\hline & & Social position & $\begin{array}{l}\text { Job, social status, self-realization, } \\
\text { professionality. }\end{array}$ \\
\hline & & Social improvement & Cooperation, respect, solidarity \\
\hline & \multirow{2}{*}{ Transcendental values } & Religious & Faith, compassion, tolerance. \\
\hline & & The greatest good & Hope, projection. \\
\hline \multirow{5}{*}{$\begin{array}{c}\text { Secondary intercultural } \\
\text { values }\end{array}$} & \multirow{3}{*}{ Intercultural values/not ethics } & Cultural knowledge & Truth, science, creativity. \\
\hline & & Educational interest & Ratio, thinking, logic, study. \\
\hline & & Cultural environment & Norms, tradition. \\
\hline & \multirow{2}{*}{ Productive values } & Material assets & Usefulness, efficiency, efficacy. \\
\hline & & Social commodities & Appreciation, estimation, attention. \\
\hline \multirow{11}{*}{ Tertiary intercultural values } & \multirow{3}{*}{ Life values } & Basic needs & Satisfaction, vitality. \\
\hline & & Leisure needs & Delight, joy \\
\hline & & Human health and hygiene & Health, well-being, cleaning \\
\hline & \multirow{3}{*}{ Affective values } & Family relationship & $\begin{array}{l}\text { Calmness, social acceptance, } \\
\text { confidence. }\end{array}$ \\
\hline & & Friend relationship & $\begin{array}{l}\text { Comprehension, love, empathy, } \\
\text { friendship. }\end{array}$ \\
\hline & & Partnership & Hope, loyalty, sexuality \\
\hline & \multirow{2}{*}{ Aesthetic values } & Beauty & Harmony, balance, clarity, tidy \\
\hline & & Artistic activity & Expression, originality, ability \\
\hline & \multirow[b]{3}{*}{ Personal development } & Self-realization & $\begin{array}{l}\text { Autonomy, self-reliance, } \\
\text { independence }\end{array}$ \\
\hline & & Self-assertion & Freedom, choice, decision. \\
\hline & & Personal attributes & $\begin{array}{l}\text { Sympathy, perseverance, diligence, } \\
\text { gratitude, kindness, humility, } \\
\text { simplicity, poverty, honesty, } \\
\text { patience, nobility, prudence, } \\
\text { maturity, bravery, experience, calm, } \\
\text { Intelligence, optimism, sweetness. }\end{array}$ \\
\hline
\end{tabular}




\section{Appendix B. Results}

Table 2. Frequency of categories of intercultural values in Albania, Germany, Armenia, Azerbaijan, Belarus, Belgium, Bosnia \& Herzegovina, Cyprus, Croatia and Denmark

\begin{tabular}{|c|c|c|c|c|c|c|c|c|c|c|c|}
\hline \multirow{2}{*}{ Dimension } & \multirow{2}{*}{ Categories } & \multicolumn{10}{|c|}{$\%$ Basic Educational Laws } \\
\hline & & Albania & Germany & Armenia & Azerbaijan & Belgium & Belarus & $\mathrm{B} \& \mathrm{H}^{1}$ & Cyprus & Croatia & Denmark \\
\hline \multirow{3}{*}{ Primary } & Moral \& ethics & 65.89 & 20 & 44.23 & 14.29 & 33.34 & 50.69 & 50 & 17.01 & 37.04 & 58.83 \\
\hline & Socials & 27.92 & 80 & 19.87 & 24.68 & 50 & 20.55 & 65 & 23.40 & 59,26 & 11.76 \\
\hline & Transcendental & 2.27 & 0 & 1.92 & 1.30 & 16.67 & 2.74 & 5 & 0 & 0 & 5.88 \\
\hline \multirow{3}{*}{ Secondary } & $\begin{array}{c}\text { Intellectuals /non } \\
\text { ethics }\end{array}$ & 0.32 & 0 & 23.07 & 40.92 & 0 & 10.96 & 25 & 25.53 & 3,70 & 17,64 \\
\hline & Productive & 0.32 & 0 & 0 & 1.30 & 0 & 0 & 0 & 0 & 0 & 0 \\
\hline & To change & 0 & 0 & 0 & 0 & 0 & 0 & 0 & 0 & 0 & 0 \\
\hline \multirow{5}{*}{ Tertiary } & Vitals & 2.92 & 0 & 6.40 & 3.90 & 0 & 8.22 & 0 & 23.39 & 0 & 5.88 \\
\hline & Affective & 0 & 0 & 5.76 & 1.95 & 0 & 0 & 0 & 0 & 0 & 0 \\
\hline & Aesthetics & 0 & 0 & 1.92 & 1.30 & 0 & 2.74 & 0 & 4.26 & 0 & 0 \\
\hline & $\begin{array}{c}\text { Personal } \\
\text { development }\end{array}$ & 0.32 & 0 & 4.48 & 10.39 & 0 & 4.11 & 0 & 6.39 & 0 & 0 \\
\hline & Ecologic & 0 & 0 & 0 & 0 & 0 & 0 & 0 & 0 & 0 & 0 \\
\hline
\end{tabular}

(1) Bosnia \& Herzegovina.

Table 3. Frequency of categories of intercultural values in Spain, Estonia, Finland, France, Greece, Hungary, Iceland, Ireland and Italy

\begin{tabular}{|c|c|c|c|c|c|c|c|c|c|c|c|}
\hline \multirow{2}{*}{ Dimension } & \multirow{2}{*}{ Categories } & \multicolumn{10}{|c|}{ \% Basic Educational Laws } \\
\hline & & Spain & Slovakia & Estonia & Finland & France & Greece & Hungary & Ireland & Iceland & Italy \\
\hline \multirow{3}{*}{ Primary } & Moral \& ethics & 58.49 & 0 & 63.65 & 42.86 & 0 & 59.13 & 50 & 80 & 71.43 & 62.45 \\
\hline & Socials & 20.75 & 40 & 15.91 & 57.15 & 25 & 27.25 & 50 & 20 & 8.04 & 18.20 \\
\hline & Transcendental & 1.88 & 0 & 0 & 0 & 0 & 0 & 0 & 0 & 0.89 & 1.50 \\
\hline \multirow{3}{*}{ Secondary } & Intellectuals /non ethics & 5.66 & 0 & 9.10 & 0 & 75 & 2.27 & 0 & 0 & 6.25 & 4.69 \\
\hline & Productive & 1.88 & 0 & 0 & 0 & 0 & 2.27 & 0 & 0 & 0 & 2.30 \\
\hline & Change & 0 & 0 & 0 & 0 & 0 & 0 & 0 & 0 & 0 & 0 \\
\hline \multirow{5}{*}{ Tertiary } & Vitals & 0 & 40 & 4.55 & 0 & 0 & 6.82 & 0 & 0 & 10,72 & 0 \\
\hline & Effectives & 0 & 0 & 0 & 0 & 0 & 0 & 0 & 0 & 0 & 0 \\
\hline & Aesthetics & 0 & 0 & 0 & 0 & 0 & 0 & 0 & 0 & 1.79 & 0 \\
\hline & Personal development & 11.32 & 20 & 6.81 & 0 & 0 & 2.27 & 0 & 0 & 0.89 & 10.86 \\
\hline & Ecological & 0 & 0 & 0 & 0 & 0 & 0 & 0 & 0 & 0 & 0 \\
\hline
\end{tabular}


Table 4. Frequency of categories of intercultural values in Lithuania, Luxembourg, Malta, Norway, Netherlands, Poland, Portugal, Prague, Russia, Sweden, Turkey and United Kingdom

\begin{tabular}{|c|c|c|c|c|c|c|c|c|c|c|c|c|}
\hline \multirow{2}{*}{ Categories } & \multicolumn{12}{|c|}{$\%$ Basic Educational Laws } \\
\hline & Lithuania & Luxembourg & Malta & Norway & Netherlands & Poland & Portugal & Prague & Russia & Sweden & Turkey & UK \\
\hline Moral \& ethics & 64.44 & 14.29 & 95.65 & 33.33 & 50 & 0 & 11.90 & 2.04 & 0 & 20 & 23.81 & 30 \\
\hline Socials & 15.55 & 21.43 & 1.45 & 8.33 & 16.66 & 33.33 & 35.70 & 18.12 & 0 & 80 & 33.33 & 45 \\
\hline Transcendental & 6.66 & 10.71 & 0 & 50 & 0 & 0 & 0 & 1.17 & 0 & 0 & 0 & 25 \\
\hline $\begin{array}{c}\text { Intellectuals /non } \\
\text { ethics }\end{array}$ & 0 & 25 & 0 & 8.33 & 33.33 & 50 & 35.71 & 23.68 & 100 & 0 & 14.28 & 0 \\
\hline Productive & 4.44 & 0 & 0 & 0 & 0 & 0 & 0 & 0 & 0 & 0 & 9.52 & 0 \\
\hline Change & 0 & 0 & 0 & 0 & 0 & 0 & 0 & 0 & 0 & 0 & 0 & 0 \\
\hline Vitals & 6.66 & 3.57 & 0 & 0 & 0 & 0 & 0 & 24.56 & 0 & 0 & 9.52 & 0 \\
\hline Effectives & 0 & 10.71 & 0 & 0 & 0 & 0 & 0 & 4,38 & 0 & 0 & 4.76 & 0 \\
\hline Aesthetics & 0 & 10.71 & 1.45 & 0 & 0 & 16.66 & 7.14 & 15.79 & 0 & 0 & & 0 \\
\hline Personal development & 2.22 & 3.57 & 1.45 & 0 & 0 & 0 & 9.52 & 10.23 & 0 & 0 & 4.76 & 0 \\
\hline Ecologic & 0 & 0 & 0 & 0 & 0 & 0 & 0 & 0 & 0 & 0 & 0 & 0 \\
\hline
\end{tabular}




\section{REFERENCES}

[1] Ainscow, M. (2001). Desarrollo de las escuelas inclusivas. Ideas, propuestas y experiencias para mejorar las instituciones escolares. Madrid: Narcea.

[2] Ainscow, M. (2005). Para comprender el desarrollo del Sistema Educativo Inclusivo. Electronic Journal of Research in Educational Psychology 3(3), 5-20.

[3] Ainscow, M.; Booth, T. \& Dyson, A. (2006). Improving schools, developing inclusion. Londres: Routledge.

[4] Arnaiz, P. (2003). Educación Inclusiva: Una escuela para todos. Málaga: Editorial Aljibe.

[5] Barton, L. (2008). Estudios sobre discapacidad y la búsqueda de la inclusividad. Observations. Revista de Educación, 349, 137-152.

[6] Berruezo, P.P. (2006). Educación Inclusiva en las escuelas canadienses. Una mirada desde la perspectiva española. Revista interuniversitaria de formación del profesorado, 20, 179-207.

[7] Blanco, M.R. (2006). La equidad y la inclusión social: uno de los desafíos de la educación y la escuela hoy. Revista Electrónica Iberoamericana sobre Calidad, Eficacia y Cambio en Educación, 4, 1-15.

[8] Bristol City Council (2003). Bristol Inclusion Standard. Good Practice Guidance for Schools

[9] Buendía, L. (2007). Valores interculturales para la convivencia. En E. Soriano (Ed.), Educación para la convivencia intercultural. Madrid: La Muralla.

[10] Coulby, D. (2006). Intercultural education: theory and practice. Sociology of Education, 245-257.

[11] Declaración Universal de Derechos Humanos (1948).

[12] Echeita, G. \& Verdugo, M. A. (2005). Diez años después de la Declaración de Salamanca sobre las necesidades educativas especiales en España. Entre la retórica esperanzadora y las resistencias al cambio. Siglo Cero, 36 (1), 5-12.

[13] Escámez, J. (2004). La educación para la promoción de los Derechos Humanos de la tercera generación. Encounter on education, 5, 81-100.

[14] Figueroa, I. \& Muñoz, Y. (2014). La guía para la inclusión educativa como herramienta de autoevaluación institucional: Reporte de una Experiencia. Revista Latinoamericana de Inclusión Educativa, 8(2), 179-198.

[15] Gairín, J. (2004). Organizar la escuela intercultural. La educación en contextos multiculturales: Diversidad e Identidad. XIII Congreso nacional y II iberoamericano de Pedagogía (pp. 273- 328). Valencia: SEP.

[16] García, G. (2015). Escalas prácticas inclusivas en educación básica: confiabilidad y validez en una muestra mexicana. Revista Latinoamericana de Inclusión Educativa, 9(1), 77-93.

[17] Jester, T. (2008). Intercultural student teaching: a bridge to global competence edited by Kenneth Cushner and Sharon Brennan. Comparative Education Review, 52(2), 285-287.
[18] Jordán, J. A., Ortega, P., \& Mínguez, R. (2002). Educación intercultural y sociedad plural. Teoría de la Educación, 14, 93-119.

[19] Kant, I. (1994). Crítica de la razón práctica. México: Espasa-Calpe mexicana.

[20] Martínez, B. (2002). La educación en la diversidad en los albores del siglo XXI, en D. Forteza y M. R. Rosselló (eds.), Educación, diversidad y calidad de vida. Palma: Universitat de les Illes Balears.

[21] Medina, R. (2009). Aprendizaje y servicio solidario: una propuesta educativa para el desarrollo de la competencia ciudadana. Revista del Fórum Europeo de Administradores de la Educación, 7, 7-10.

[22] Parrilla, A. (2002). Acerca del origen y sentido de la educación inclusiva. Revista de educación, 327, 11-29.

[23] Payá, A. (2010). Políticas de educación inclusiva en América Latina. Propuestas, realidades y retos de futuro. Revista educación inclusiva, 3, 125-142.

[24] Pérez, G. (2005). Derechos Humanos y Educación Social. Revista de Educación, 19-39.

[25] Portera, A. (2004b). Stereotype, prejudice and intercultural education in Italia: research on textbooks in primary schools. Sociology of Education, 283-294.

[26] Puigdellívol, A. (2004). Actas del seminario sobre la Escuela Inclusiva curso 2003-2004. Barcelona: Graó.

[27] Rios, M., (2009). La inclusión en el área de educación física en España. Análisis de las barreras para la participación y aprendizaje. Ágora educación física y Deporte 9, 83-114.

[28] Ruiz, C. (2002). Educación intercultural. Una visión crítica. Barcelona: Octaedro.

[29] Sabariego, M. (2002). La educación intercultural. Antes los retos del siglo XXI. Bilbao: Desclée de Brouwer.

[30] Sáez Alonso, R. (2006a). La educación intercultural. Revista de Educación, 339, 859-881.

[31] Sanchez, A. et al. (2008). Percepciones y actitudes de los estudiantes de Pedagogía hacia la inclusión educativa. Estudios pedagógicos, XXXIV, 2, 169-178.

[32] Santos, M. A. (2010). Una pretensión problemática: educar para los valores y preparar para la vida. Revista de Educación, 351, 23-47.

[33] Soriano, V. (2011). La educación inclusiva en Europa. CEE Participación educativa, 18, 35-45.

[34] Thomazet, S. (2009). From Integration to Inclusive Education: Does Changing the Terms Improve Practice? International Journal of Inclusive Education, 13(6), 553-563.

[35] Tomé, M. (2012). Estudio de los valores interculturales inmersos en la Educación para la Ciudadanía melillense. Tesis doctoral. Granada: Universidad de Granada.

[36] Tomé M. \& Berrocal, E. (2013). La influencia del género en la utilización de valores democráticos que garantizan la inclusión educativa intercultural. Revista European Journal of investigation in health, psychology and education, 1, 60-73. 
[37] Tomé M.; Berrocal, E; \& Buendía, L. (2014). Intercultural values education in Europe. A comparative analysis of Norwegian and Spanish reality. Procedia-Social and Behavioral Sciences, 132, 442-446.

[38] Tomé, M. \& Nolasco, A. (2014). La educación intercultural centrada en valores democráticos. Los valores emergentes de los derechos humanos, de la carta de los derechos fundamentales de la unión europea y de la constitución española. Quaderno Digital.1.
[39] Touriñan, J. M. (2003). Sociedad civil y educación de la conciencia moral. Teoría de la Educación. Revista interuniversitaria, 15, 213-234.

[40] Touriñan, J. M. (2008). Educación en valores: Educación intercultural. Madrid: Netbiblo.

[41] Wehmeyer, M. (2009). Autodeterminación y la tercera generación de prácticas de inclusión. Revista de Educación, $349,47-6$. 